\title{
REVIEW
}

\section{Apoptosis regulation in adrenocortical carcinoma}

\author{
Sofia S Pereira ${ }^{1,2,3}$, Mariana P Monteiro ${ }^{3}$, Sonir R Antonini ${ }^{4}$ and Duarte Pignatelli, ${ }^{1,2,5}$ \\ ${ }^{1}$ Instituto de Investigação e Inovação em Saúde (I3S), Universidade do Porto, Porto, Portugal \\ ${ }^{2}$ Institute of Molecular Pathology and Immunology of the University of Porto (IPATIMUP), Porto, Portugal \\ ${ }^{3}$ Endocrine, Cardiovascular \& Metabolic Research, Department of Anatomy, Multidisciplinary Unit for Biomedical Research (UMIB), Instituto de Ciências \\ Biomédicas Abel Salazar, University of Porto (ICBAS/UP), Porto, Portugal \\ ${ }^{4}$ Department of Pediatrics, Ribeirao Preto Medical School, University of Sao Paulo, Ribeirao Preto, Brazil \\ ${ }^{5}$ Department of Endocrinology, Hospital S. João, Porto, Portugal
}

Correspondence should be addressed to D Pignatelli: dpignatelli@ipatimup.pt

\begin{abstract}
Apoptosis evading is a hallmark of cancer. Tumor cells are characterized by having an impaired apoptosis signaling, a fact that deregulates the balance between cell death and survival, leading to tumor development, invasion and resistance to treatment. In general, patients with adrenocortical carcinomas (ACC) have an extremely bad prognosis, which is related to disease progression and significant resistance to treatments. In this report, we performed an integrative review about the disruption of apoptosis in ACC that may underlie the characteristic poor prognosis in these patients. Although the apoptosis has been scarcely studied in ACC, the majority of the deregulation phenomena already described are anti-apoptotic. Most importantly, in a near future, targeting apoptosis modulation in ACC patients may become a promising therapeutic.
\end{abstract}

\section{Key Words}

- adrenocortical tumors

- adrenocortical carcinomas

- apoptosis

- molecular deregulations

\section{Adrenocortical tumors}

Adrenal cortex tumors (ACT) are common tumors with a reported prevalence above $4 \%$ in most populations (1). However, the majority of ACT are benign, non-functioning and incidentally discovered during imaging studies performed for unrelated clinical reasons $(1,2)$. On the other side, adrenocortical carcinomas (ACC) are rare but usually have an aggressive behavior and a poor prognosis $(1,3,4,5,6)$. According to the ENSAT classification, the 5 -year disease-specific survival rate is approximately $82 \%$ for stage I, $61 \%$ for stage II, $50 \%$ for stage III and 13\% for stage IV (4). This dismal clinical outcomes of ACC patients is related to the diagnosis at an advanced clinical stage and because there is no effective adjuvant or neoadjuvant therapy for late-stage diagnosed patients (7). Only few targeted therapies based on the advances in the knowledge of adrenal tumor pathophysiology were developed and up until now they generally failed in clinical settings. One of the main reasons associated to adrenal tumor cells resistance to chemotherapy is compromised apoptosis signaling, a fact that deregulates the balance between cell death and survival, thus facilitating tumor development, invasion and resistance to treatment $(8,9,10,11)$. In the following section, we will briefly review the regulation of apoptosis and then explore the abnormalities in apoptosis in ACC that have been reported to date.

\section{Caspases alterations}

There are two main apoptosis activation pathways: the extrinsic one that involves activation of cell death receptors and the intrinsic cascade. The latter is also known as the mitochondrial pathway, as it involves the permeation of the mitochondrial outer membrane followed by the release of apoptotic intervenients $(12,13)$. Both apoptosis pathways converge into caspase activation and cellular disintegration (12).
This work is licensed under a Creative Commons Attribution-NonCommercial 4.0 International License. ded from Bioscientifica.com at 04/26/2023 07:52:02AM 
Table 1 Classification of caspases according to the point of entry into the apoptosis cascade.

\begin{tabular}{|c|c|c|c|}
\hline \multicolumn{2}{|c|}{ Initiator caspases } & \multirow[b]{2}{*}{$\begin{array}{l}\text { Executioner } \\
\text { caspases }\end{array}$} & \multirow[b]{2}{*}{$\begin{array}{l}\text { Inflammatory } \\
\text { caspases }\end{array}$} \\
\hline $\begin{array}{l}\text { Extrinsic } \\
\text { pathway }\end{array}$ & $\begin{array}{l}\text { Intrinsic } \\
\text { pathway }\end{array}$ & & \\
\hline Caspase 8 & Caspase $2 \uparrow$ & Caspase $3 \downarrow$ & Caspase 1 \\
\hline \multirow[t]{3}{*}{ Caspase 10} & Caspase $9 \downarrow$ & Caspase 6 & Caspase 4 \\
\hline & & Caspase 7 & Caspase 5 \\
\hline & & & Caspase 12 \\
\hline
\end{tabular}

$\downarrow$ represents the caspases that are underexpressed in adult ACC, $\uparrow$ represents the overexpression caspases.

Caspases are a family of cysteine proteases that play a crucial role at apoptosis $(14,15)$. Caspases can be classified as initiators or executioners, according to the point of entry into the apoptosis cascade (Table 1) (15). Initiator caspases such as caspase- 8 and caspase- 10 are characterized by containing a death effector domain (DED), involved in the extrinsic apoptosis pathway. Alternatively, the caspases involved in the intrinsic apoptosis pathway such as caspase- 2 and caspase- 9 contain a caspase recruitment domain (CARD). These caspases are able to cleave and activate executioner caspases: caspase-3, caspase- 6 and caspase-7. A third group of caspases including caspase-1, caspase-4, caspase-5 and caspase-12 participate in innate immune responses rather than in the apoptotic cascade (16).

Initiator caspases are produced as inactive monomeric procaspases and are activated by dimerization via the designated 'induced proximity model' $(16,17)$. The executioner caspases are also produced as inactive procaspases and they require cleavage by the initiator caspases in order to be activated $(16,18)$. Executioner caspases, when activated are able to cleave and activate Rho-associated protein kinase (ROCK-1) and p21activated kinase 2 (PAK-2), by removing the inhibitory domain. Both, ROCK-1 and PAK-2 induce myosin regulatory light-chain (MLC) phosphorylation that results in cell shrinkage and cell membrane blebbing $(19,20)$. In addition, executioner caspases cleave DNA fragmentation factors (DFF) in two fragments: the DFF40 and its inhibitor DFF45. This cleavage allows DFF40 translocation into the cell nucleus, which induces DNA double-strand breaks resulting in DNA fragmentation (Fig. 1) $(21,22)$.

In ACC occurring in adulthood, the expression of genes that encode initiator caspases (caspase- 2 and caspase-9) involved in the intrinsic apoptosis pathway was found to be altered (Table 1) (23). The expression of CASP9 was decreased in ACC while the CASP2 was increased when compared with adrenocortical adenomas (ACAs) (23). The executioner CASP3 expression was found to be decreased in ACC compared with ACAs as well as with normal adrenal glands. On the contrary, in ACT occurring in childhood, the caspases CASP3, CASP8 and CASP9 have been studied and their expression was not found to be different in malignant when compared to benign ACT (24). Concerning prognostic differences in children with ACC, a low CASP3 expression was found

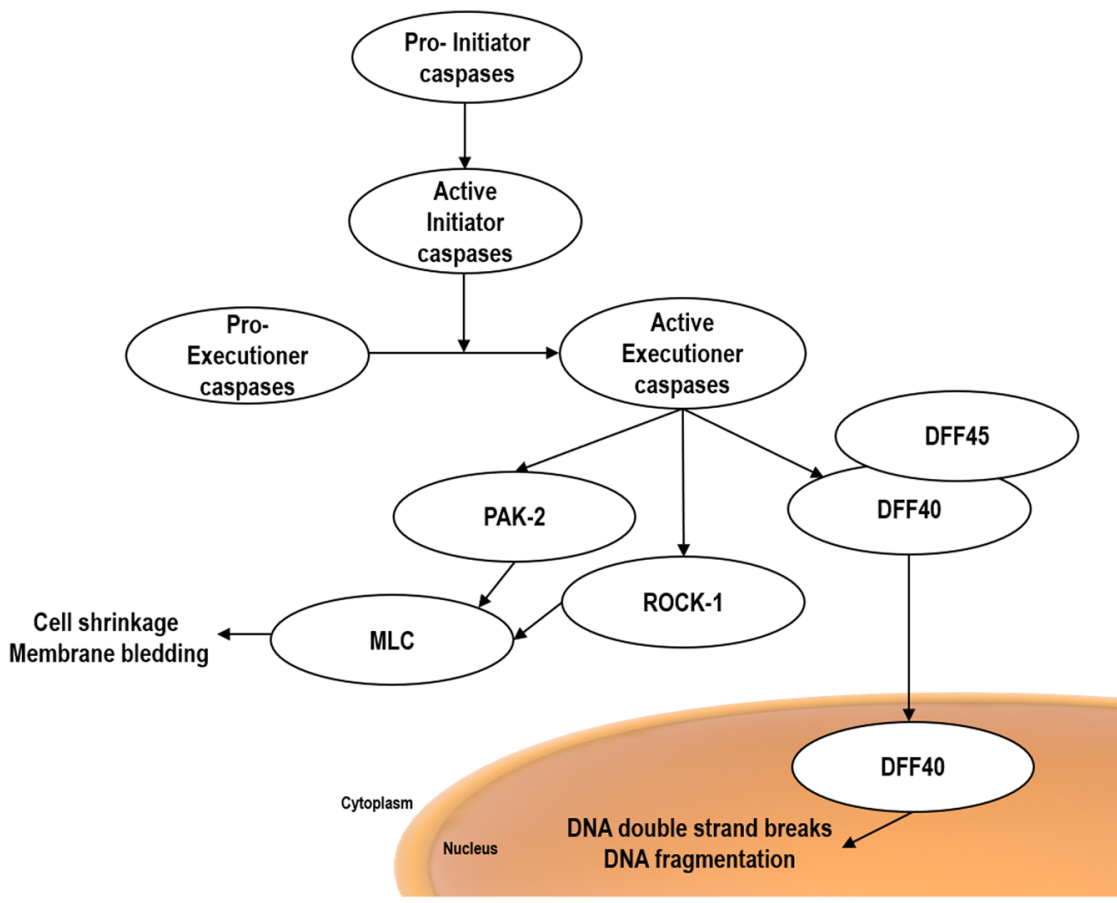

Figure 1

Schematic representation of apoptosis regulated by caspases. After activation of the initiator caspases, they activate executioner caspases by cleavage. Executioner caspases, when activated cleave and activate ROCK-1, PAK-2 and DFF40/45 leading to cell shrinkage, membrane blebbing and DNA fragmentation. 
to be associated with a lower 5-year event-free survival, while low levels of CASP9 were associated with a higher 5 -year event-free survival (24). Also, a significant negative correlation between CASP3 expression and tumor size was found in adults with ACC.

\section{Extrinsic apoptosis signaling pathway alterations}

The apoptosis extrinsic pathway is triggered by extracellular ligands that activate the death receptors located in the plasma membrane. These receptors possess a cytosolic death domain $(12,25,26)$.

The most well-known ligands and their respective death receptors are fatty acid synthetase ligand (FasL)/ fatty acid synthetase receptor (Fas); TNF-related apoptosisinducing ligand (TRAIL)/death receptor 4 and 5 (DR4 and DR5) and tumor necrosis factor $\alpha(\mathrm{TNF}-\alpha) /$ tumor necrosis factor receptor 1 (TNF1-R) $(12,25,26)$.

FasL binding to Fas, triggers the aggregation of Fas trimers and the recruitment of the death domaincontaining protein (FADD) that binds to Fas death domain (Fig. 2) (12, 27). Besides, FADD presents a DED domain that allows initiator caspases binding, such as pro-caspase 8 , creating a death-inducing signaling complex (DISC) $(12,26)$. DISC formation then causes the cleavage of procaspase 8 into active caspase 8 . The activation of initiator caspases can then cleave and activate executioner caspases $(13,16)$. Moreover, caspase 8 also cleaves and activates BH3 interacting domain death agonist (Bid) that releases mitochondrial cytochrome c, which can also activate caspase 3 (28).

The activation of DR4 and DR5 by TRAIL triggers a similar pathway as the one described for Fas-induced apoptosis with the recruitment FADD and pro-caspase 8 to form DISC (Fig. 2) $(12,13)$.

Fas expression was found to be reduced and FasL expression increased in ACC when compared with ACA and normal adrenal glands (29). Another group reported that Fas gene expression was absent in all analyzed ACC and present in ACA and normal adrenal glands (30). On the other side, soluble Fas antigen (sFas) plasma levels were also observed to be higher in patients with ACT than in healthy blood donors. sFas plasma levels were particularly higher in patients with aldosterone producing adenomas. In addition, sFas plasma levels were positively correlated with the ACC size $(31,32)$. In childhood ACT, Fas gene expression was lower in ACT when compared with normal adrenal glands, but no differences were observed between ACC and ACA (24)

$\mathrm{TNF} \alpha$ binding to the extracellular domain of TNF1-R leads to the binding of the TNF receptor-associated death domain (TRADD) adaptor protein to the intracellular domain of TNF1-R, resulting in the recruitment of the receptor interacting protein (RIP), FADD and TNF-Rassociated factor (TRAF). FADD recruitment then leads into the signaling apoptosis pathway, while RIP activates the nuclear factor of $\kappa \mathrm{B}(\mathrm{NF}-\kappa \mathrm{B})$ through stimulation of the inhibitor of $\kappa B$-kinase (IKK) and TRAF activates the JNK pathway stimulating the transcription factor, activating protein-1 (AP-1) (Fig. 2) $(12,25,26)$.

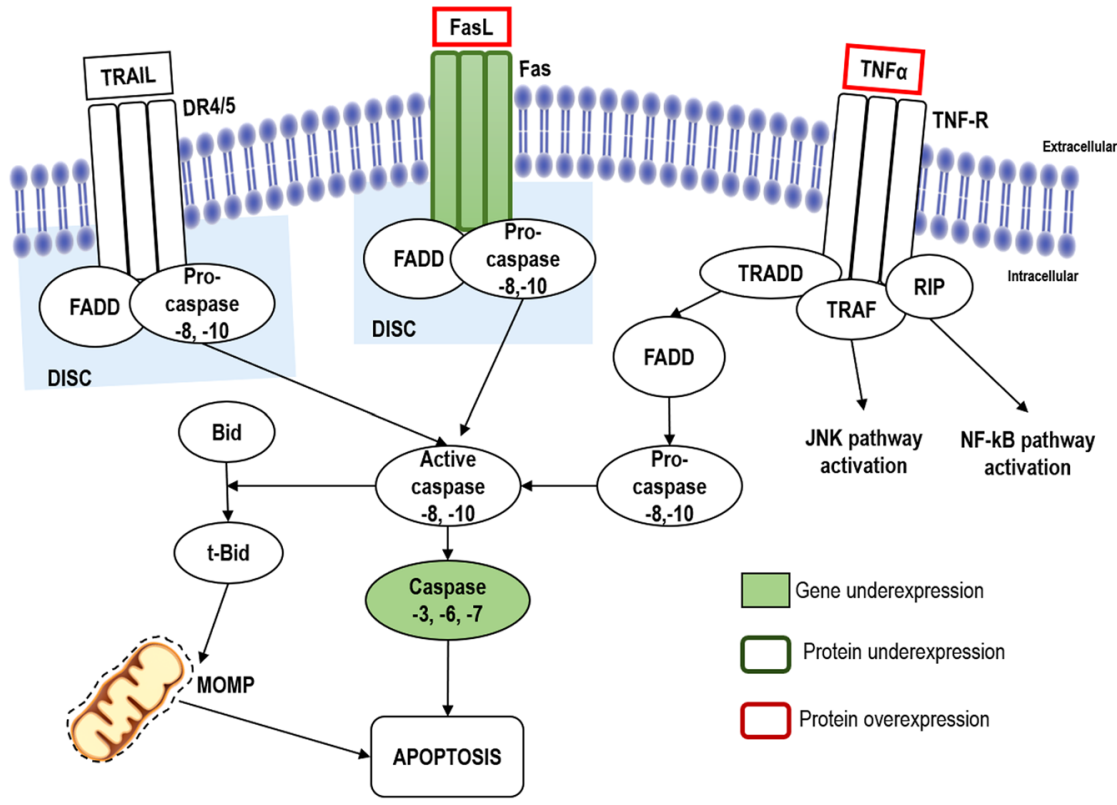

Figure 2

Schematic representation of extrinsic apoptotic pathway. Stimulation of death receptors of the TNF-R, Fas and DR4/5 by their respective ligands, results in receptor aggregation and recruitment of FADD and caspase- 8 and caspase- 10 . These caspases become activated and cleaves the executioner caspases-3, caspase- 6 and caspase-7, leading to apoptosis. Abnormalities in mRNA and in protein expression alterations already described in adrenocortical carcinomas are highlighted in solid and open squares, respectively.

https://ec.bioscientifica.com https://doi.org/10.1530/EC-19-0114 (c) 2019 The authors Published by Bioscientifica Ltd

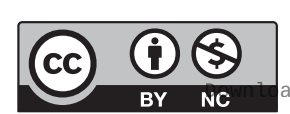

This work is licensed under a Creative Commons Attribution-NonCommercial 4.0 International License. ded from Bioscientifica.com at 04/26/2023 07:52:02AM via free access 
Although TNF gene expression was not found to be altered in ACC, the tumor necrosis factor alpha-induced protein 3 (TNFAIP3), a ubiquitin-modifying enzyme that negatively regulates TNF response, was found to be overexpressed in ACC when compared to the normal adrenal gland. Moreover, high TNFAIP3 expression was significantly associated with poor overall survival of ACC patients (33). TNFRSF19, a gene that encodes a member of the TNF receptor superfamily, was also found to be overexpressed in ACC and it was associated with poor prognosis in another study (23).

TNF $\alpha$ serum levels were significantly higher in patients with ACT before adrenalectomy when compared to healthy subjects. TNFo serum levels were particularly higher in patients with ACC and aldosteronomas. In contrast, soluble TNF receptors (TNF1-R and TNF2-R) serum levels were similar in ACT patients and in healthy subjects. Following adrenalectomy, TNF $\alpha$ levels decreased in patients with ACC, non-functioning ACA and in patients with aldosteronomas. On the other hand, reduction of TNF1-R and TNF2-R serum levels was observed only in patients with unilateral aldosteronomas (34).

TNF expression was significantly lower in childhood ACC when compared with ACA and associated with a lower 5-year event-free survival (24). In these pediatric patients, a strong and moderate immunoreactivity for TNF- $\alpha$ protein expression was associated with a higher 5 -year event-free and overall survival (24).

Tumor necrosis factor receptor-associated factor 4 (TRAF4), a mediator of the TNF-induced signaling pathway, is able to inhibit the Fas-induced apoptosis (35). TRAF4 overexpression was associated with poor prognosis in patients with ACC (23).

\section{Intrinsic apoptosis pathway signaling alterations}

The intrinsic apoptosis pathway is triggered by intracellular stimuli that include DNA damage, absence of growth factors, oxidative stress and endoplasmic reticulum stress (13). These stimuli lead to mitochondrial outer membrane permeation (MOMP) resulting in the release of pro-apoptotic factors such as cytochrome c and other intermembrane space proteins such as Smac/ DIABLO, HtrA2/Omi, apoptosis-inducing factor (AIF) and Endonuclease G (EndoG) (Fig. 3). Cytochrome c binds to the apoptotic protease-activating factor-1 (APAF-1) inducing its oligomerization, a conformational change that leads to apoptosome formation. The apoptosome then binds and activates pro-caspase 9 to caspase 9, which is then able to activate the executioner caspases 3,6 and $7(12,36,37)$. Smac/DIABLO and HtrA2/Omi potentiate caspase activation, since they are antagonists of the inhibitors of apoptosis proteins (IAPs). IAPs are able to inhibit activated executioner caspases stopping the caspase-dependent apoptosis $(26,38,39)$. After being released from mitochondria, caspase-independent cell death effectors AIF and EndoG translocate to the nucleus and trigger nuclear condensation and DNA fragmentation $(40,41)$.

MOMP is regulated by the members of the Bcl-2 family $(26,42,43)$. There are three types of Bcl-2 family proteins based in their apoptotic function and Bcl-2 homology domains (BH1, 2, 3 and 4) (42): (1) the anti-apoptotic proteins that contain 3 or $4 \mathrm{BH}$ domains, like Bcl-2, $\mathrm{Bcl}-\mathrm{x}_{\mathrm{L}}$ and Bcl-w; (2) the pro-apoptotic proteins that contain 2 or $3 \mathrm{BH}$ domains, like Bax, Bak and Bok (3) the BH3only proteins that are also pro-apoptotic but have only the BH3 domain, like Bad, Bik, Bid, Noxa and Puma (26, $44,45,46,47,48,49,50,51)$. Anti-apoptotic proteins are able to inhibit MOMP by sequestering BH3-only proteins and/or Bax/Bak $(43,52,53)$. MOMP only occurs when the anti-apoptotic Bcl-2 family proteins are inhibited and Bax or Bak are activated by the activator BH3-only proteins thus inducing Bax/Bak oligomerization $(43,53)$.

$B C L 2$ expression levels were found to be higher in ACC when compared with non-functioning ACA, while the Bax gene expression was found to be similar among all the different ACT analyzed by Ando et al. (54). This finding was not confirmed in subsequent studies where $B C L 2$ and $B C L X L$ gene expression was similar among ACC, ACA and normal adrenal glands $(30,55)$. Bax gene expression was absent in ACC, implying a reduction in apoptosis, whereas it was always present in ACA and normal adrenal glands (55). In another study, the BCL2L12 gene that encodes another anti-apoptotic Bcl-2 family protein was increased in the ACC, while the Bok gene that encodes a pro-apoptotic Bcl-2 family protein were described to be increased in ACC with poor prognosis (23).

In pediatric patients with $A C T, B C L 2$ gene expression was similar in ACC, ACA and normal adrenal glands. However, lower BCL2 gene and protein expression were associated with poor prognosis in these pediatric patients with ACC (24). In contrast, another study in pediatric patients did not find an association between Bcl-2 protein expression and prognosis (56).

In adult patients, $\mathrm{Bcl}-2$ protein expression was found to be similarly increased in ACC and non-functioning ACA when compared with normal adrenal glands in a

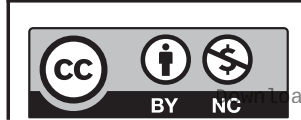

This work is licensed under a Creative Commons Attribution-NonCommercial 4.0 International License. ded from Bioscientifica.com at 04/26/2023 07:52:02AM 


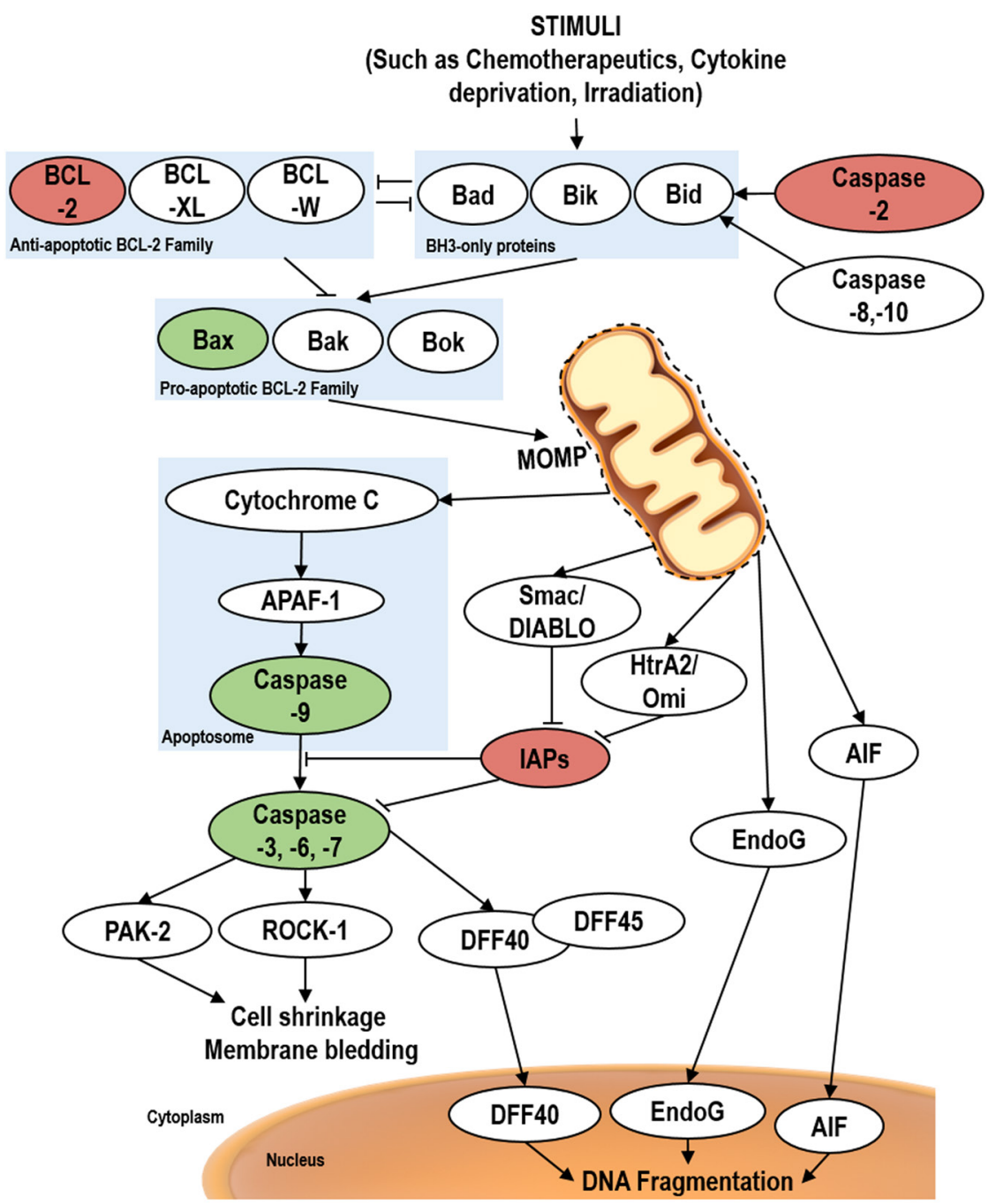

Gene underexpression

Gene overexpression

\section{Figure 3}

Schematic representation of intrinsic apoptotic pathway. Stress signals leads to the pro-apoptotic $\mathrm{BCL}-2$ family proteins activation that induce the mitochondrial outer membrane permeation (MOMP). MOMP allows the release of the Cytochrome C, AlF, EndoG, HtrA2/Omi and Smac/ DIABLO. Cytochrome $C$ release leads to the formation of apoptosome complex that triggers caspase-3, -6, - 7 activation. They cleave ROCK-1, PAK-2 and DFF40/45 leading to cell shrinkage, membrane blebbing and DNA fragmentation. HtrA2/Omi and Smac/DIABLO inhibit IAPs, avoiding the caspase inhibition by them. EndoG and AIF lead to DNA fragmentation. Abnormalities in the expression of genes involved in the intrinsic apoptotic pathway in adrenocortical carcinomas are highlighted in red or green circles. single study (57). However, these results have not been confirmed in several other studies $(58,59,60,61)$.

The IAPs family have been highly studied in the context of the cancer due to their key role in the regulation of apoptosis mostly through the direct inhibition of executioner caspases $(62,63)$.

Altieri et al. studied three elements of the IAPs family: MLIAP/livin/BIRC7, survivin/BIRC5 and XIAP/BIRC4. They found that increased livin mRNA and protein levels were promising markers for malignancy diagnosis in ACT. BIRC5 expression was found to be similar between ACC and ACA but higher than that in normal adrenal glands (64). Contrarily, other authors found that BIRC5 expression is increased in the ACC group $(23,65)$. Survivin expression was found to have a negative impact on overall survival in patients with ACC (64); increased survivin was found in more aggressive tumors $(23,65)$. Although increased in ACC, no association was observed between livin expression and ACC aggressiveness features (64).

\section{Cell cycle and apoptosis regulation}

Cell cycle instabilities can lead to apoptosis. Some cell cycle genes are also involved in apoptosis regulation, of which TP53, $c-m y c$ and $p R B / E 2 F$ are the most well-known examples $(12,66,67)$.

p53 is involved in both intrinsic and extrinsic apoptotic pathways. However, its main role occurs in the intrinsic pathway $(68,69)$. After DNA damage, p53 and MDM2 are phosphorylated, which inhibits their interaction resulting in p53 accumulation in the nucleus 
and activation of transcription of various pro-apoptotic genes including Bax, Noxa, Puma, BID, Fas, APAF-1, DR5. In addition, p53 accumulation in the nucleus represses anti-apoptotic genes transcription, such as BIRC5 that encodes survivin, a member of the IAP family $(68,69,70$, $71,72,73)$. Moreover, p53 can bind directly to the antiapoptotic proteins, Bcl-2 and Bcl-xL, and also translocate to mitochondria inducing Bax/Bak oligomerization, thus promoting MOMP (74). It has also been described that P53 overexpression increases Fas levels at the cell surface, by promoting its trafficking from Golgi complex. Finally, p53 can also activate DR5 $(75,76)$.

TP53 mutations usually result in the loss of p53 tumor suppressive activity, mainly due to repression of p53 target genes transactivation (77). TP53 mutations in ACT was demonstrated to be absent in the majority of ACA. In contrast, the prevalence of somatic TP53 mutations in sporadic ACC can varies from 20 to $30 \%$ of the cases $(78,79,80,81)$. Besides that, the majority of ACC patients with mutated TP53 were observed to have poor outcomes (78). Aberrant p53 protein expression was also found to be associated with decreased disease-free survival (80). However, in ACC p53 expression was found to be highly variable (5-52\%). Thus, p53 expression cannot be considered a reliable molecular marker to identify ACC $(58,61,82,83,84)$. Still, loss of heterozygosity (LOH) in chromosome $17 \mathrm{q} 13$ harboring TP53 was demonstrated to be present in approximately $80 \%$ of ACC. Nevertheless, $\mathrm{LOH}$ at $17 \mathrm{q} 13$ is not always associated with TP53 mutations suggesting that other genes in the same chromosomal region contribute to ACC biology $(85,86,87)$.

TP53 gene germline pathogenic variants are typically associated with Li-Fraumeni or Li-Fraumeni-like syndrome, which is associated with an hereditary predisposition to neoplasms, in particular to pediatric ACC (88).

Contrarily to the majority of mutations associated with LFS that are in p53 DNA-binding domain, 80\% of pediatric ACC have mutations in p53 oligomerization domain, in particular in the exon 10 of the short arm of chromosome 17 (p.R337H). p.R337H mutation appears to be particularly prevalent in Southeast and Southern Brazilian populations, where the incidence of pediatric ACT is estimated to be 10-15 times higher than worldwide $(89,90,91)$. In vivo studies found that this mutation is associated to an increased DNA damage, a mildly decreased apoptosis and cell cycle arrest. These tumor-suppressive activity alterations have been proposed to be sufficient to induce tumorigenesis and to confer tumor growth advantages $(92,93)$. Otherwise, genomic profiles of ACC with p.R337H mutation were found to be similar to ACC with a different TP53 mutation (94). Pediatric ACT with p.R337H mutation were found to have a significantly lower expression of apoptosis-related genes when compared to non-neoplastic adrenals (24).

The cross-talk between c-Myc and p53 is important for driving cell decision to undergo apoptosis in response to stress $(95,96)$. c-Myc can also drive apoptosis in a manner that does not require p53 $(96,97)$. c-Myc is able to suppress anti-apoptotic Bcl-2 family members and to induce the expression or activation of pro-apoptotic Bcl-2 proteins, such as Bax, Bak and Bim and transcriptionally activate Bax $(95,98,99,100)$. Besides that, c-Myc overexpression sensitizes cells to the apoptotic action of TNF and TRAIL death ligands (101). Furthermore, c-Myc also inhibits the activation of anti-apoptotic c-Jun kinases and NF-kB (95, 102). In ACC, c-Myc was found to be underexpressed compared to ACA and to the normal adrenal cortex (23, $103,104,105,106)$.

Loss of pRB induces apoptosis and the mechanisms behind this phenomena are mainly related to the action of the E2F transcription factors, the well-known targets of pRB (107). The cytochrome c, AIF and SMAC are transcriptionally regulated by E2F1 $(108,109,110)$. Deathinducing-protein (DIP) is located in the mitochondria and mediates E2F1-induced apoptosis, in a p53-independent pathway. In E2F1-activated cells, DIP suppression results in a decrease of apoptosis $(111,112)$. The loss of pRB was suggested to be a marker of poor prognosis as it appears to be a characteristic of the more aggressive ACC (113). A significant overexpression of E2F genes was found in ACC $(104,114)$. However, contrarily to expected, DIP was found to be underexpressed when compared with ACA (23).

\section{miRNAs and apoptosis}

miRNAs are non-coding RNAs that are able to silence their target genes at post-transcriptional level. Functional studies showed that abnormal miRNA expression is a key to cancer development by abnormally regulating several cellular processes, including apoptosis. Studies on ACC showed that deregulated miRNAs expression is able to negative modulate ACC apoptosis $(115,116)$.

miRNA-483-3p was found to be overexpressed in ACC compared with ACA $(116,117)$. This miRNA is able to protect the cancer cells from apoptosis through the negative modulation of the pro-apoptotic protein PUMA. A combination of the expression of the miR-483-3p and Smad4, a critical effector in the TGF- $\beta$ signaling pathway, was demonstrated to have more powerful diagnostic

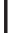

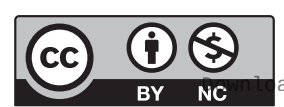


accuracy than the classic pathology Weiss score system alone (117). Another study found that miR-483-3p is an excellent marker for the differential diagnosis between ACC and ACA. Higher miR-483-3p was found in ACC and there was no overlap between ACC and ACA (118).

Wu et al. found that miRNA-205 was significantly decreased in ACC compared with ACA. miRNA-205 was able to activate Bcl-2, in ACC tumor cells, leading to the activation of the intrinsic apoptosis pathway by activating caspase-9 and caspase-3 (119).

miR-195 is also downregulated in ACC compared to ACA (120). Low expression of miR-195 was significantly associated with poor overall survival (120). In the ACC cell line H295R, the restoration of the miR-195 expression led to increased expression of caspase-3, resulting in decreased cell viability. This finding in ACC confirmed the role of miR-195 on promoting apoptosis (116). In line with this finding, in colorectal tumors the miR-195 targeted Bcl-2 and induced apoptosis (121).

\section{Apoptosis as a therapeutic target in ACC}

Several in vitro and in vivo studies have attempted to improve the prognosis of patients with cancer by targeting apoptosis pathways either by targeting the overexpressed anti-apoptotic proteins or by stimulating pro-apoptotic molecules expression (9). These studies reported great potential of apoptosis-targeted therapies. Some of these have focused on reducing anti-apoptotic proteins such as the Bcl-2 family proteins, IAPs or c-FLIP (cellular FLICE (FADD-like IL-1 $\beta$-converting enzyme)-inhibitory protein) in order to allow the activation of apoptosis $(62,63,122$, 123). In ACC few studies were performed in order to evaluate the efficacy of those therapies $(64,65,124,125)$.

Gossypol is a polyphenolic compound extracted from cotton plants with the ability of binding to the anti-apoptotic proteins, Bcl-2 and $\mathrm{Bcl}-\mathrm{x}_{\mathrm{L}}$ inhibiting them (126). In 1991, a study found that this compound has multiple inhibitory effects on adrenal steroidogenesis (127). Some years later, a trial of this compound was performed in 18 patients with metastatic ACC and the authors found that three patients that were refractory to chemotherapeutic agents had partial responses and one patient had stable disease. However, the majority of the patients had tumor progression (124). The low therapeutic response of Gossypol was considered similar to the other medical therapies available. Later, some studies found that Gossypol presents two stereoisomers and that the (-) Gossypol stereoisomer is the one with highest affinity for Bcl-2 and Bcl- $\mathrm{x}_{\mathrm{L}}(126,128,129)$. Since the drug used before was a mixture between the two stereoisomers, the use of the (-) Gossypol alone may have better effects compared to what was observed in the ACC patients. The compound (-) Gossypol, actually known as AT-101, has already been tested in clinical trials in patients with prostate cancer, leukemia and lung cancer (130, 131, 132). In ACC, only pre-clinical in vitro and in vivo studies were performed with that drug. Schteingart et al. studied the effects of (-) Gossypol in two ACC cell lines, H295 which is a cell line with low levels of Bcl- $\mathrm{x}_{\mathrm{L}}$ and RL25, that presents high levels of $\mathrm{Bcl}-\mathrm{x}_{\mathrm{L}}$. The authors demonstrated that the expression of Bcl- $\mathrm{x}_{\mathrm{L}}$ influences the effects of the drug, since better results were found in the RL25 cell line with a complete suppression of the tumor growth (125).

Some studies also performed pre-clinical studies in order to evaluate the efficacy of the IAPs in inhibit ACC. Sbiera et al. knocked down survivin expression by siRNA transfection in an ACC cell line and it doubled the apoptosis rates comparing to the non-transfected cells treated with etoposide. The authors also studied if survivin inhibition could be a sensitizing factor to chemotherapeutic drugs. However, the treatment with addition of etoposide to the survivin siRNA-transfected ACC cells showed only a slight increase in the apoptosis rate (65).

Altieri et al. studied the efficacy of another IAP (livin) in ACC cell lines. Using livin transfected H295R cells, they observed the expected decrease in Casp3 levels. However, no differences in the cell viability and proliferation were observed, suggesting that additional mechanisms are possibly involved in the already complex mechanism of the apoptotic cascade in ACC (64).

Evaluation of the apoptosis are highly used to verify the cancer efficiency of drugs but mostly in pre-clinical studies. In ACC cell lines, the efficacy of a given drug in increasing the apoptosis rate has been mainly studied using the Annexin V/Propidium Iodide assay, TUNEL assay and the final apoptotic molecules involved, such as the executioner caspases $(133,134)$. Unfortunately, it does not give us the full comprehensive mechanistic understanding of tumoral apoptosis inductor. Table 2 summarizes the available studies targeting ACC and their relationship with apoptosis.

\section{Clinical implications of apoptosis alterations in ACC}

The balance between cell death and survival becomes compromised when apoptosis signaling is deregulated, thus conferring advantages for tumorigenesis and

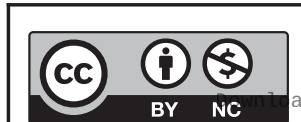

This work is licensed under a Creative Commons Attribution-NonCommercial 4.0 International License. ded from Bioscientifica.com at 04/26/2023 07:52:02AM 
Table 2 Drugs that positively increased the ACC apoptosis rate in in vitro and in vivo studies.

\begin{tabular}{l}
\hline Anti-ACC drugs \\
\hline AMG 900
\end{tabular}

ATR-101 (PD132301-02)

Cholesterol free SHDL nanoparticles in combination with cisplatin, etoposide or mitotane

Docosahexenoic acid

DZNep

Erlotinib and NVP-AEW541

combination

Fingolimod (FTY720)

G-1

Metformin

Mitotane (drug used in ACC patients)

Niclosamide

Rapamycin

Rottlerin

Drug type
Aurora kinase inhibitor
Adrenalytic activity
inhibitor

efflux cholesterol inducer

$$
\begin{aligned}
& \text { n-3 polyunsaturated fatty } \\
& \text { acid/mTOR complex } 1 / 2 \\
& \text { inhibitor } \\
& \text { EZH2 (histone modifier) } \\
& \text { inhibitor }
\end{aligned}
$$

EGFR and IGF1R inhibitor

Sphingosine kinase 1 antagonist

Non-steroidal G proteincoupled estrogen receptor agonist

Biguanide cationic agent

Steroidogenesis inhibitor and cytostatic antineoplastic

Anti-helminthic agent

mTOR complex 1 inhibitor

Anti-helminthic or fertilization antagonist

Method to evaluate apoptosis
Annexin V-FITC apoptosis
detection assay
TUNEL assay
Annexin V-FITC apoptosis
detection assay
Annexin V-FITC apoptosis
detection assay

Annexin V-FITC Apoptosis

Detection assay

TUNEL assay

$B C L 2, B C L-X L$ and $B I R C 5$

expression/Caspase 3 activity

assay/TUNEL assay

Annexin V-FITC apoptosis detection assay

Annexin V-FITC apoptosis

detection assay

Annexin V-FITC Apoptosis

Detection assay/Caspase 9 and

3/7 activity assay/TUNEL assay

Annexin $\vee$ Apoptosis Detection

assay/Bcl-xl, Bcl-2, Bcl-w and

Cleaved Caspase 3 expression

Annexin V Apoptosis Detection

assay/Bax, Bak and $\mathrm{BCl}-2$

expression

Caspase 3/7 activity assay

Caspase $3 / 7$ activity assay

Cleaved Caspase 3 expression

TUNEL assay

Annexin V-FITC Apoptosis

Detection assay

\begin{tabular}{l} 
Samples type \\
\hline ACC cell line $\mathrm{NCl}-\mathrm{H} 295$ \\
$\mathrm{NCl}-\mathrm{H} 295 \mathrm{R}$ \\
xenographs \\
ACC cell line $\mathrm{NCl}-\mathrm{H} 295$ \\
ACC cell lines: SW-13 \\
and $\mathrm{NCl}-\mathrm{H} 295 \mathrm{R}$
\end{tabular}

Ref.

(141)

ACC cell lines: SW-13 and $\mathrm{NCl}-\mathrm{H} 295 \mathrm{R}$

SW-13 xenographs

$\mathrm{ACC}$ cell line $\mathrm{NCl}$ -

H295R

ACC cell lines: SW-13 and $\mathrm{NCl}-\mathrm{H} 295 \mathrm{R}$

ACC cell lines: SW-13 and $\mathrm{NCl}-\mathrm{H} 295 \mathrm{R}$

ACC cell line $\mathrm{NCl}$ H295R

ACC cell line $\mathrm{NCl}$ H295R

ACC cell line $\mathrm{NCl}-\mathrm{H} 295$

ACC cell line $\mathrm{NCl}-$ H295R

ACC cell lines: BD140A, H295R

Adrenocortical tumors from AdTAg mice

SW-13 xenographs

ACC cell lines: SW-13 and $\mathrm{NCl}-\mathrm{H} 295 \mathrm{R}$

ACC, adrenocortical carcinomas; AMG, urora kinases inhibitor; Bak, B-cell lymphoma 2 homologous antagonist/killer; Bax, B-cell lymphoma 2-associated X protein; BCL-2, B-cell lymphoma 2; BCL-W, B-cell lymphoma-like 2; BCL-XL, B-cell lymphoma-extra-large; BIRC5, Baculoviral IAP repeat containing 5; DZNep, Deazaneplanocin A; EGFR, epidermal growth factor receptor; EZH2, enhancer of zeste homolog 2; FITC, fluorescein isothiocyanate; IGFR, insulin growth factor receptor; mTOR, mammalian target of rapamycin; NCI, National Cancer Institute; sHDL, synthetic high-density lipoprotein; TUNEL, terminal deoxynucleotidyl transferase dUTP nick end labeling.

tumor growth $(8,9,10,11)$. The detailed knowledge on the status of apoptosis regulation in ACC can result in pivotal clues that could be translated into the clinical practice, by modifying current therapeutic interventions. Although few alterations in apoptosis regulation were reported in ACC, some of these were shown to be promising.

miR-483-3p, a negative modulator of pro-apoptotic proteins, is overexpressed in ACC depicting a poor prognosis. So miR-483-3p was appointed not only to be an important mechanistic alteration for ACC tumorigenesis and tumor progression, but also demonstrated its diagnostic utility by depicting a more powerful diagnostic accuracy to assess ACC tumor grade than the Weiss score that is currently used in routine clinical practice (116, $117,118)$.

TP53 was described as one of ACC driver genes in several studies, including the most recent pan-genomic studies $(81,135) . \mathrm{LOH}$ in the chromosome were TP53 is harbored and TP53 mutations are the most frequent alterations observed in ACC, leading to abnormal cell cycle progression and apoptosis inhibition $(78,79,80,81$, $85,86,87)$. Targeted therapies with the goal of recovering or reactivating p53 function in TP53 mutants were 
already developed and are currently being tested for the treatment of several tumors, other than ACC (e.g. PRIMA-1 ${ }^{\text {MET }}$ and MDM2 antagonists) (136). The high prevalence of alterations related to TP53 in ACC makes these tumors good candidates for TP53 modulators therapies.

Survivin, a member of the apoptosis inhibitor protein family, was found to have a negative impact in ACC patients' survival and was pointed as a promising ACC drug target $(23,64,65)$. Although the development of effective survivin inhibitors was hampered by a few reported challenges, several potent survivin inhibitors were already tested in clinical trials for some cancers (137, 138), other than ACC.

Finally, some authors demonstrated that antiapoptotic molecules expression, such as members of the Bcl-2 family, are able to influence the effectiveness of some drugs, providing an additional rationale for the outcomes variability observed in clinical trials (139). So, when possible, profiling ACC for anti-apoptosis genes expression could be recommended in order to improve the predictability of outcomes achieved and even enable a more personalized treatment approach for ACC patients. (Reviewer \#1, Comment \#1)

\section{Conclusions}

Apoptosis evading is one of well-known process leading to cancer cells proliferation and expansion. It is also a very important hallmark of cancer (140). Tumor cells are not only characterized by genetic alterations leading to increased proliferation but also by a compromised apoptosis signaling, a fact that adds to the imbalance between cell death and survival, leading to tumor development, invasion and resistance to treatment $(8,9,10,11)$. Decreased apoptosis in ACC associated with their aggressiveness and the resistance to treatment was observed in ACC patients. In ACC, pro-apoptotic factors are generally inhibited and anti-apoptotic ones are generally increased. However, although promising, the attempts to revert these alterations in ACC cell lines and in xenograft models have led to insufficient results to date. More studies are needed in order to integrate the key players involved in the apoptosis in ACC and to translate this information into the clinical practice. Unraveling all defects in apoptosis in ACC may have a significant importance either as therapeutic targets or molecular markers for ACC diagnosis or prognosis. So far, none of these expectations has been accomplished.

\section{Declaration of interest}

The authors declare that there is no conflict of interest that could be perceived as prejudicing the impartiality of this review.

\section{Funding}

The work was supported by the Foundation for Science and Technology (FCT) (PTDC/MEC-ONC/31384/2017). Unit for Multidisciplinary Research in Biomedicine (UMIB) is funded by grants from FCT (UID/Multi/00215/2013).

\section{References}

1 Else T, Kim AC, Sabolch A, Raymond VM, Kandathil A, Caoili EM, Jolly S, Miller BS, Giordano TJ \& Hammer GD. Adrenocortical carcinoma. Endocrine Reviews 201435 282-326. (https://doi. org/10.1210/er.2013-1029)

2 Pignatelli D. Adrenal cortex tumors and hyperplasias. In Contemporary Aspects of Endocrinology. London, UK: IntechOpen. (https://doi.org/10.5772/19108)

3 Chagpar R, Siperstein AE \& Berber E. Adrenocortical cancer update. Surgical Clinics of North America 201494 669-687. (https://doi. org/10.1016/j.suc.2014.02.009)

4 Roman S. Adrenocortical carcinoma. Current Opinion in Oncology 2006 18 36-42. (https://doi.org/10.1097/01.cco.0000198976.43992.14)

5 Libe R, Borget I, Ronchi CL, Zaggia B, Kroiss M, Kerkhofs T, Bertherat J, Volante M, Quinkler M, Chabre O, et al. Prognostic factors in stage III-IV adrenocortical carcinomas (ACC): an European Network for the Study of Adrenal Tumor (ENSAT) study. Annals of Oncology 201526 2119-2125. (https://doi.org/10.1093/annonc/ mdv329)

6 Fassnacht M, Libe R, Kroiss M \& Allolio B. Adrenocortical carcinoma: a clinician's update. Nature Reviews: Endocrinology 20117 323-335. (https://doi.org/10.1038/nrendo.2010.235)

7 Fassnacht M, Johanssen S, Quinkler M, Bucsky P, Willenberg HS, Beuschlein F, Terzolo M, Mueller HH, Hahner S, Allolio B, et al. Limited prognostic value of the 2004 International Union Against Cancer staging classification for adrenocortical carcinoma: proposal for a revised TNM classification. Cancer 2009115 243-250. (https:// doi.org/10.1002/cncr.24030)

8 Fulda S. Evasion of apoptosis as a cellular stress response in cancer. International Journal of Cell Biology 20102010 370835. (https://doi. org/10.1155/2010/370835)

9 Hassan M, Watari H, AbuAlmaaty A, Ohba Y \& Sakuragi N. Apoptosis and molecular targeting therapy in cancer. BioMed Research International 20142014 1-23. (https://doi.org/10.1155/2014/150845)

10 Plati J, Bucur O \& Khosravi-Far R. Dysregulation of apoptotic signaling in cancer: molecular mechanisms and therapeutic opportunities. Journal of Cellular Biochemistry 2008104 1124-1149. (https://doi.org/10.1002/jcb.21707)

11 Fernald K \& Kurokawa M. Evading apoptosis in cancer. Trends in Cell Biology 201323 620-633. (https://doi.org/10.1016/j.tcb.2013.07.006)

12 Lawen A. Apoptosis-an introduction. BioEssays 200325 888-896. (https://doi.org/10.1002/bies.10329)

13 Elmore S. Apoptosis: a review of programmed cell death. Toxicologic Pathology 200735 495-516. (https://doi. org/10.1080/01926230701320337)

14 Grutter MG. Caspases: key players in programmed cell death. Current Opinion in Structural Biology 200010 649-655. (https://doi. org/10.1016/S0959-440X(00)00146-9)

15 Boatright KM \& Salvesen GS. Mechanisms of caspase activation. Current Opinion in Cell Biology 200315 725-731. (https://doi. org/10.1016/j.ceb.2003.10.009)

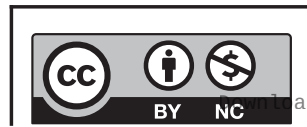

This work is licensed under a Creative Commons Attribution-NonCommercial 4.0 International License. ded from Bioscientifica.com at 04/26/2023 07:52:02AM 
16 McIlwain DR, Berger T \& Mak TW. Caspase functions in cell death and disease. Cold Spring Harbor Perspectives in Biology 20157 a026716. (https://doi.org/10.1101/cshperspect.a008656)

17 Boatright KM, Renatus M, Scott FL, Sperandio S, Shin H, Pedersen IM, Ricci JE, Edris WA, Sutherlin DP, Green DR, et al. A unified model for apical caspase activation. Molecular Cell $2003 \mathbf{1 1}$ 529-541. (https://doi.org/10.1016/S1097-2765(03)00051-0)

18 Riedl SJ \& Shi Y. Molecular mechanisms of caspase regulation during apoptosis. Nature Reviews: Molecular Cell Biology 20045 897-907. (https://doi.org/10.1038/nrm1496)

19 Radu M, Semenova G, Kosoff R \& Chernoff J. PAK signalling during the development and progression of cancer. Nature Reviews: Cancer 201414 13-25. (https://doi.org/10.1038/nrc3645)

20 Riento K \& Ridley AJ. Rocks: multifunctional kinases in cell behaviour. Nature Reviews: Molecular Cell Biology 20034 446-456. (https://doi.org/10.1038/nrm1128)

21 Liu X, Zou H, Slaughter C \& Wang X. DFF, a heterodimeric protein that functions downstream of caspase-3 to trigger DNA fragmentation during apoptosis. Cell 199789 175-184. (https://doi. org/10.1016/S0092-8674(00)80197-X)

22 Liu X, Zou H, Widlak P, Garrard W \& Wang X. Activation of the apoptotic endonuclease DFF40 (caspase-activated DNase or nuclease). Oligomerization and direct interaction with histone H1. Journal of Biological Chemistry 1999274 13836-13840. (https://doi. org/10.1074/jbc.274.20.13836)

23 de Reynies A, Assie G, Rickman DS, Tissier F, Groussin L, ReneCorail F, Dousset B, Bertagna X, Clauser E \& Bertherat J. Gene expression profiling reveals a new classification of adrenocortical tumors and identifies molecular predictors of malignancy and survival. Journal of Clinical Oncology 200927 1108-1115. (https://doi. org/10.1200/JCO.2008.18.5678)

24 Lorea CF, Moreno DA, Borges KS, Martinelli CE, Jr, Antonini SR, de Castro M, Tucci S, Jr, Neder L, Ramalho LN, Cardinalli I, et al. Expression profile of apoptosis-related genes in childhood adrenocortical tumors: low level of expression of BCL2 and TNF genes suggests a poor prognosis. European Journal of Endocrinology 2012167 199-208. (https://doi.org/10.1530/EJE-12-0183)

25 Ashkenazi A. Targeting death and decoy receptors of the tumournecrosis factor superfamily. Nature Reviews Cancer 20022 420-430. (https://doi.org/10.1038/nrc821)

26 Xu G \& Shi Y. Apoptosis signaling pathways and lymphocyte homeostasis. Cell Research 200717 759-771. (https://doi. org/10.1038/cr.2007.52)

27 Nagata S. Fas ligand-induced apoptosis. Annual Review of Genetics 199933 29-55. (https://doi.org/10.1146/annurev.genet.33.1.29)

$28 \mathrm{Li} \mathrm{H}$, Zhu H, Xu CJ \& Yuan J. Cleavage of BID by caspase 8 mediates the mitochondrial damage in the Fas pathway of apoptosis. Cell 1998 94 491-501. (https://doi.org/10.1016/S0092-8674(00)81590-1)

29 Wolkersdorfer GW, Marx C, Brown J, Schroder S, Fussel M, Rieber EP, Kuhlisch E, Ehninger G \& Bornstein SR. Prevalence of HLA-DRB1 genotype and altered Fas/Fas ligand expression in adrenocortical carcinoma. Journal of Clinical Endocrinology and Metabolism 200590 1768-1774. (https://doi.org/10.1210/jc.2004-1406)

30 Kanauchi H, Wada N, Ginzinger DG, Yu M, Wong MG, Clark OH \& Duh QY. Diagnostic and prognostic value of fas and telomericrepeat binding factor-1 genes in adrenal tumors. Journal of Clinical Endocrinology and Metabolism 200388 3690-3693. (https://doi. org/10.1210/jc.2002-020965)

31 Kushlinskii NE, Britvin TA, Polyakova GA, Abbasova SG, Baronin AA, Bogatyrev OP, Kalinin AP \& Lipkin VM. Soluble Fas antigen (sFAS) in the serum from patients with adrenal tumors. Bulletin of Experimental Biology and Medicine 2001132 990-992. (https://doi. org/10.1023/A:1013683731516)

32 Kushlinskii NE, Britvin TA, Polyakova GA, Abbasova SG, Baronini AA, Tishenina RS, Molchanova GS, Sel'chuk VY, Pirogov DA, Bogatyrev OP, et al. Plasma content of soluble fas antigen in patients with adrenal tumors and tumor-like pathologies. Bulletin of Experimental Biology and Medicine 2002134 171-174. (https://doi.org/10.1023/A:1021196517353)

33 Hantel C, Ozimek A, Lira R, Ragazzon B, Jackel C, Frantsev R, Reincke M, Bertherat J, Mussack T \& Beuschlein F. TNF alpha signaling is associated with therapeutic responsiveness to vascular disrupting agents in endocrine tumors. Molecular and Cellular Endocrinology 2016423 87-95. (https://doi.org/10.1016/j. mce.2015.12.009)

34 Komorowski J, Jurczynska J, Stepien T, Kolomecki K, Kuzdak K \& Stepien H. Serum concentrations of TNF alpha and its soluble receptors in patients with adrenal tumors treated by surgery. International Journal of Molecular Sciences 201011 2281-2290. (https://doi.org/10.3390/ijms11062281)

35 Fleckenstein DS, Dirks WG, Drexler HG \& Quentmeier H. Tumor necrosis factor receptor-associated factor (TRAF) 4 is a new binding partner for the p70S6 serine/threonine kinase. Leukemia Research 200327 687-694. (https://doi.org/10.1016/S0145-2126(02)00325-9)

36 Landes T \& Martinou JC. Mitochondrial outer membrane permeabilization during apoptosis: the role of mitochondrial fission. Biochimica and Biophysica Acta 20111813 540-545. (https://doi. org/10.1016/j.bbamcr.2011.01.021)

37 Parsons MJ \& Green DR. Mitochondria in cell death. Essays in Biochemistry 201047 99-114. (https://doi.org/10.1042/bse0470099)

38 Berthelet J \& Dubrez L. Regulation of apoptosis by inhibitors of apoptosis (IAPs). Cells 20132 163-187. (https://doi.org/10.3390/ cells2010163)

39 Yang QH, Church-Hajduk R, Ren J, Newton ML \& Du C. Omi/ HtrA2 catalytic cleavage of inhibitor of apoptosis (IAP) irreversibly inactivates IAPs and facilitates caspase activity in apoptosis. Genes and Development 200317 1487-1496. (https://doi.org/10.1101/ gad.1097903)

40 Li LY, Luo X \& Wang X. Endonuclease G is an apoptotic DNase when released from mitochondria. Nature 2001412 95-99. (https://doi. org/10.1038/35083620)

41 Susin SA, Lorenzo HK, Zamzami N, Marzo I, Snow BE, Brothers GM, Mangion J, Jacotot E, Costantini P, Loeffler M, et al. Molecular characterization of mitochondrial apoptosis-inducing factor. Nature 1999397 441-446. (https://doi.org/10.1038/17135)

42 Kuwana T \& Newmeyer DD. Bcl-2-family proteins and the role of mitochondria in apoptosis. Current Opinion in Cell Biology 200315 691-699. (https://doi.org/10.1016/j.ceb.2003.10.004)

43 Gillies LA \& Kuwana T. Apoptosis regulation at the mitochondrial outer membrane. Journal of Cellular Biochemistry 2014115 632-640. (https://doi.org/10.1002/jcb.24709)

44 Boise LH, Gonzalez-Garcia M, Postema CE, Ding L, Lindsten T, Turka LA, Mao X, Nunez G \& Thompson CB. bcl-x, a bcl-2-related gene that functions as a dominant regulator of apoptotic cell death. Cell 199374 597-608. (https://doi.org/10.1016/00928674(93)90508-N)

45 Gibson L, Holmgreen SP, Huang DC, Bernard O, Copeland NG, Jenkins NA, Sutherland GR, Baker E, Adams JM \& Cory S. bcl-w, a novel member of the bcl-2 family, promotes cell survival. Oncogene 199613 665-675.

46 Chittenden T, Flemington C, Houghton AB, Ebb RG, Gallo GJ, Elangovan B, Chinnadurai G \& Lutz RJ. A conserved domain in Bak, distinct from $\mathrm{BH} 1$ and $\mathrm{BH} 2$, mediates cell death and protein binding functions. EMBO Journal 199514 5589-5596. (https://doi. org/10.1002/j.1460-2075.1995.tb00246.x)

47 Oltvai ZN, Milliman CL \& Korsmeyer SJ. Bcl-2 heterodimerizes in vivo with a conserved homolog, Bax, that accelerates programmed cell death. Cell 199374 609-619. (https://doi.org/10.1016/00928674(93)90509-O)

48 Hsu SY \& Hsueh AJ. A splicing variant of the Bcl-2 member Bok with a truncated BH3 domain induces apoptosis but does not dimerize with antiapoptotic Bcl-2 proteins in vitro. Journal of Biological

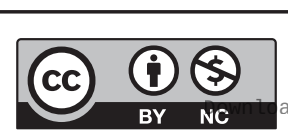

This work is licensed under a Creative Commons Attribution-NonCommercial 4.0 International License. Aed from Bioscientifica com at 04/26/2023 07:52:02AM 
Chemistry 1998273 30139-30146. (https://doi.org/10.1074/ jbc.273.46.30139)

49 Yang E, Zha J, Jockel J, Boise LH, Thompson CB \& Korsmeyer SJ. $\mathrm{Bad}$, a heterodimeric partner for Bcl-XL and Bcl-2, displaces Bax and promotes cell death. Cell 199580 285-291. (https://doi. org/10.1016/0092-8674(95)90411-5)

50 Wang K, Yin XM, Chao DT, Milliman CL \& Korsmeyer SJ. BID: a novel BH3 domain-only death agonist. Genes and Development 1996 10 2859-2869. (https://doi.org/10.1101/gad.10.22.2859)

51 Boyd JM, Gallo GJ, Elangovan B, Houghton AB, Malstrom S, Avery BJ, Ebb RG, Subramanian T, Chittenden T \& Lutz RJ. Bik, a novel death-inducing protein shares a distinct sequence motif with Bcl-2 family proteins and interacts with viral and cellular survivalpromoting proteins. Oncogene 199511 1921-1928.

52 Billen LP, Kokoski CL, Lovell JF, Leber B \& Andrews DW. Bcl-XI inhibits membrane permeabilization by competing with Bax. PLoS Biology 20086 e147. (https://doi.org/10.1371/journal.pbio.0060147)

53 Du H, Wolf J, Schafer B, Moldoveanu T, Chipuk JE \& Kuwana T. BH3 domains other than Bim and Bid can directly activate Bax/ Bak. Journal of Biological Chemistry 2011286 491-501. (https://doi. org/10.1074/jbc.M110.167148)

54 Ando T, Shibata H, Suzuki T, Kurihara I, Hayashi K, Hayashi M, Saito I, Kawabe H, Tsujioka M \& Saruta T. The possible role of apoptosis-suppressing genes, bcl-2 and mcl-1/EAT in human adrenal tumors. Endocrine Research 199824 955-960. (https://doi. org/10.3109/07435809809032715)

55 Kanauchi H, Wada N, Clark OH \& Duh QY. Apoptosis regulating genes, bcl- 2 and bax, and human telomerase reverse transcriptase messenger RNA expression in adrenal tumors: possible diagnostic and prognostic importance. Surgery 2002132 1021-1026; discussion 1026-1027. (https://doi.org/10.1067/msy.2002.128616)

56 Sbragia L, Oliveira-Filho AG, Vassallo J, Pinto GA, Guerra-Junior G \& Bustorff-Silva J. Adrenocortical tumors in Brazilian children: immunohistochemical markers and prognostic factors. Archives of Pathology and Laboratory Medicine 2005129 1127-1131. (https://doi. org/10.1043/1543-2165(2005)129[1127:ATIBCI]2.0.CO;2)

57 Bernini GP, Moretti A, Viacava P, Bonadio AG, Iacconi P, Miccoli P $\&$ Salvetti A. Apoptosis control and proliferation marker in human normal and neoplastic adrenocortical tissues. British Journal of Cancer 200286 1561-1565. (https://doi.org/10.1038/sj.bjc.6600287)

58 Stojadinovic A, Brennan MF, Hoos A, Omeroglu A, Leung DH, Dudas ME, Nissan A, Cordon-Cardo C \& Ghossein RA. Adrenocortical adenoma and carcinoma: histopathological and molecular comparative analysis. Modern Pathology 200316 742-751. (https://doi.org/10.1097/01.MP.0000081730.72305.81)

59 Stojadinovic A, Ghossein RA, Hoos A, Nissan A, Marshall D, Dudas M, Cordon-Cardo C, Jaques DP \& Brennan MF. Adrenocortical carcinoma: clinical, morphologic, and molecular characterization. Journal of Clinical Oncology 200220 941-950. (https://doi. org/10.1200/JCO.2002.20.4.941)

60 Zhang PJ, Genega EM, Tomaszewski JE, Pasha TL \& LiVolsi VA. The role of calretinin, inhibin, melan-A, BCL-2, and C-kit in differentiating adrenal cortical and medullary tumors: an immunohistochemical study. Modern Pathology 200316 591-597. (https://doi.org/10.1097/01.MP.0000073134.60541.E8)

61 McNicol AM, Struthers AL, Nolan CE, Hermans J \& Haak HR. Proliferation in adrenocortical tumors: correlation with clinical outcome and p53 status. Endocrine Pathology 19978 29-36. (https:// doi.org/10.1007/BF02739705)

62 Hunter AM, LaCasse EC \& Korneluk RG. The inhibitors of apoptosis (IAPs) as cancer targets. Apoptosis 200712 1543-1568. (https://doi org/10.1007/s10495-007-0087-3)

63 Saleem M, Qadir MI, Perveen N, Ahmad B, Saleem U, Irshad T \& Ahmad B. Inhibitors of apoptotic proteins: new targets for anticancer therapy. Chemical Biology and Drug Design 201382 243-251. (https:// doi.org/10.1111/cbdd.12176)
64 Altieri B, Sbiera S, Della Casa S, Weigand I, Wild V, Steinhauer S, Fadda G, Kocot A, Bekteshi M, Mambretti EM, et al. Livin/ BIRC7 expression as malignancy marker in adrenocortical tumors. Oncotarget 20178 9323-9338. (https://doi.org/10.18632/ oncotarget.14067)

65 Sbiera S, Kroiss M, Thamm T, Beyer M, Majidi F, Kuehner D, Wobser M, Becker JC, Adam P, Ronchi C, et al. Survivin in adrenocortical tumors - pathophysiological implications and therapeutic potential. Hormone and Metabolic Research 201345 137-146. (https://doi.org/10.1055/s-0032-1327750)

66 Pucci B, Kasten M \& Giordano A. Cell cycle and apoptosis. Neoplasia 20002 291-299. (https://doi.org/10.1038/sj.neo.7900101)

67 Pereira SS, Monteiro MP, Bourdeau I, Lacroix A \& Pignatelli D. MECHANISMS of ENDOCRINOLOGY: Cell cycle regulation in adrenocortical carcinoma. European Journal of Endocrinology 2018179 R95-R110. (https://doi.org/10.1530/EJE-17-0976)

68 Amaral JD, Xavier JM, Steer CJ \& Rodrigues CM. The role of p53 in apoptosis. Discovery Medicine 20109 145-152.

69 Chipuk JE \& Green DR. Dissecting p53-dependent apoptosis. Cell Death and Differentiation 200613 994-1002. (https://doi. org/10.1038/sj.cdd.4401908)

70 Hoffman WH, Biade S, Zilfou JT, Chen J \& Murphy M. Transcriptional repression of the anti-apoptotic survivin gene by wild type p53. Journal of Biological Chemistry 2002277 3247-3257. (https://doi.org/10.1074/jbc.M106643200)

71 Miyashita T \& Reed JC. Tumor suppressor p53 is a direct transcriptional activator of the human bax gene. Cell $1995 \mathbf{8 0}$ 293-299. (https://doi.org/10.1016/0092-8674(95)90412-3)

72 Nakano K \& Vousden KH. PUMA, a novel proapoptotic gene, is induced by p53. Molecular Cell 20017 683-694. (https://doi. org/10.1016/S1097-2765(01)00214-3)

73 Oda E, Ohki R, Murasawa H, Nemoto J, Shibue T, Yamashita T, Tokino T, Taniguchi T \& Tanaka N. Noxa, a BH3-only member of the Bcl-2 family and candidate mediator of p53-induced apoptosis. Science 2000288 1053-1058. (https://doi.org/10.1126/ science.288.5468.1053)

74 Schuler M \& Green DR. Transcription, apoptosis and p53: catch22. Trends in Genetics 200521 182-187. (https://doi.org/10.1016/j tig.2005.01.001)

75 Bennett M, Macdonald K, Chan SW, Luzio JP, Simari R \& Weissberg P. Cell surface trafficking of Fas: a rapid mechanism of p53-mediated apoptosis. Science 1998282 290-293. (https://doi.org/10.1126/ science.282.5387.290)

76 Wu GS, Burns TF, McDonald ER 3rd, Jiang W, Meng R, Krantz ID, Kao G, Gan DD, Zhou JY, Muschel R, et al. KILLER/DR5 is a DNA damage-inducible p53-regulated death receptor gene. Nature Genetics 199717 141-143. (https://doi.org/10.1038/ng1097-141)

77 Robles AI \& Harris CC. Clinical outcomes and correlates of TP53 mutations and cancer. Cold Spring Harbor Perspectives in Biology 2010 2 a001016. (https://doi.org/10.1101/cshperspect.a001016)

78 Ragazzon B, Libe R, Gaujoux S, Assie G, Fratticci A, Launay P, Clauser E, Bertagna X, Tissier F, de Reynies A, et al. Transcriptome analysis reveals that p53 and \{beta\}-catenin alterations occur in a group of aggressive adrenocortical cancers. Cancer Research 201070 8276-8281. (https://doi.org/10.1158/0008-5472.CAN-10-2014)

79 Barzon L, Chilosi M, Fallo F, Martignoni G, Montagna L, Palu G \& Boscaro M. Molecular analysis of CDKN1C and TP53 in sporadic adrenal tumors. European Journal of Endocrinology 2001145 207-212. (https://doi.org/10.1530/eje.0.1450207)

80 Waldmann J, Patsalis N, Fendrich V, Langer P, Saeger W, Chaloupka B, Ramaswamy A, Fassnacht M, Bartsch DK \& Slater EP. Clinical impact of TP53 alterations in adrenocortical carcinomas. Langenbeck's Archives of Surgery 2012397 209-216. (https://doi. org/10.1007/s00423-011-0868-6)

81 Zheng S, Cherniack AD, Dewal N, Moffitt RA, Danilova L, Murray BA, Lerario AM, Else T, Knijnenburg TA, Ciriello G, et al. Comprehensive 
pan-genomic characterization of adrenocortical carcinoma. Cancer Cell 201629 723-736. (https://doi.org/10.1016/j.ccell.2016.04.002)

82 Arola J, Salmenkivi K, Liu J, Kahri AI \& Heikkila P. p53 and Ki67 in adrenocortical tumors. Endocrine Research 200026 861-865. (https:// doi.org/10.3109/07435800009048609)

83 Reincke M, Karl M, Travis WH, Mastorakos G, Allolio B, Linehan HM \& Chrousos GP. p53 mutations in human adrenocortical neoplasms: immunohistochemical and molecular studies. Journal of Clinical Endocrinology and Metabolism 199478 790-794. (https://doi. org/10.1210/jcem.78.3.8126158)

84 Pereira SS, Morais T, Costa MM, Monteiro MP \& Pignatelli D. The emerging role of the molecular marker p27 in the differential diagnosis of adrenocortical tumors. Endocrine Connections 20132 137-145. (https://doi.org/10.1530/EC-13-0025)

85 Libe R, Groussin L, Tissier F, Elie C, Rene-Corail F, Fratticci A, Jullian E, Beck-Peccoz P, Bertagna X, Gicquel C, et al. Somatic TP53 mutations are relatively rare among adrenocortical cancers with the frequent 17p13 loss of heterozygosity. Clinical Cancer Research 2007 13 844-850. (https://doi.org/10.1158/1078-0432.CCR-06-2085)

86 Gicquel C, Bertagna X, Gaston V, Coste J, Louvel A, Baudin E, Bertherat J, Chapuis Y, Duclos JM, Schlumberger M, et al. Molecular markers and long-term recurrences in a large cohort of patients with sporadic adrenocortical tumors. Cancer Research 200161 6762-6767.

87 Juhlin CC, Goh G, Healy JM, Fonseca AL, Scholl UI, Stenman A, Kunstman JW, Brown TC, Overton JD, Mane SM, et al. Whole-exome sequencing characterizes the landscape of somatic mutations and copy number alterations in adrenocortical carcinoma. Journal of Clinical Endocrinology and Metabolism 2015100 E493-E502. (https:// doi.org/10.1210/jc.2014-3282)

88 Varley JM. Germline TP53 mutations and Li-Fraumeni syndrome. Human Mutation 200321 313-320. (https://doi.org/10.1002/ humu.10185)

89 Ribeiro RC, Sandrini F, Figueiredo B, Zambetti GP, Michalkiewicz E, Lafferty AR, DeLacerda L, Rabin M, Cadwell C, Sampaio G, et al. An inherited p53 mutation that contributes in a tissue-specific manner to pediatric adrenal cortical carcinoma. PNAS $2001989330-9335$. (https://doi.org/10.1073/pnas.161479898)

90 Sandrini F, Villani DP, Tucci S, Moreira AC, de Castro M \& Elias LL. Inheritance of R337H p53 gene mutation in children with sporadic adrenocortical tumor. Hormone and Metabolic Research 200537 231-235. (https://doi.org/10.1055/s-2005-861373)

91 Almeida MQ \& Latronico AC. The molecular pathogenesis of childhood adrenocortical tumors. Hormone and Metabolic Research 200739 461-466. (https://doi.org/10.1055/s-2007-981476)

92 Park JH, Li J, Starost MF, Liu C, Zhuang J, Chen J, Achatz MI, Kang JG, Wang PY, Savage SA, et al. Mouse homolog of the human TP53 R337H mutation reveals its role in tumorigenesis. Cancer Research 201878 5375-5383. (https://doi.org/10.1158/0008-5472. CAN-18-0016)

93 Borges LM \& Ayres FM. R337H mutation of the TP53 gene as a clinical marker in cancer patients: a systematic review of literature. Genetics and Molecular Research 201514 17034-17043. (https://doi. org/10.4238/2015.December.16.4)

94 Lalli E \& Figueiredo BC. Pediatric adrenocortical tumors: what they can tell us on adrenal development and comparison with adult adrenal tumors. Frontiers in Endocrinology 20156 23. (https://doi. org/10.3389/fendo.2015.00023)

95 Hoffman B \& Liebermann DA. Apoptotic signaling by c-MYC. Oncogene 200827 6462-6472. (https://doi.org/10.1038/ onc.2008.312)

96 Prendergast GC. Mechanisms of apoptosis by c-Myc. Oncogene 1999 18 2967-2987. (https://doi.org/10.1038/sj.onc.1202727)

97 McMahon SB. MYC and the control of apoptosis. Cold Spring Harbor Perspectives in Medicine 20144 a014407-a014407. (https://doi. org/10.1101/cshperspect.a014407)
98 Mitchell KO, Ricci MS, Miyashita T, Dicker DT, Jin Z, Reed JC \& El-Deiry WS. Bax is a transcriptional target and mediator of c-mycinduced apoptosis. Cancer Research $2000606318-6325$.

99 Maclean KH, Keller UB, Rodriguez-Galindo C, Nilsson JA \& Cleveland JL. c-Myc augments gamma irradiation-induced apoptosis by suppressing Bcl-XL. Molecular and Cellular Biology 200323 7256-7270. (https://doi.org/10.1128/MCB.23.20.7256-7270.2003)

100 Luscher B. Function and regulation of the transcription factors of the Myc/Max/Mad network. Gene 2001277 1-14. (https://doi. org/10.1016/S0378-1119(01)00697-7)

101 Nieminen AI, Partanen JI, Hau A \& Klefstrom J. c-Myc primed mitochondria determine cellular sensitivity to TRAIL-induced apoptosis. EMBO Journal 200726 1055-1067. (https://doi. org/10.1038/sj.emboj.7601551)

102 Klefstrom J, Arighi E, Littlewood T, Jaattela M, Saksela E, Evan GI \& Alitalo K. Induction of TNF-sensitive cellular phenotype by c-Myc involves p53 and impaired NF-kappaB activation. EMBO Journal 1997 16 7382-7392. (https://doi.org/10.1093/emboj/16.24.7382)

103 Giordano TJ, Kuick R, Else T, Gauger PG, Vinco M, Bauersfeld J, Sanders D, Thomas DG, Doherty G \& Hammer G. Molecular classification and prognostication of adrenocortical tumors by transcriptome profiling. Clinical Cancer Research 200915 668-676. (https://doi.org/10.1158/1078-0432.CCR-08-1067)

104 Tombol Z, Szabo PM, Molnar V, Wiener Z, Tolgyesi G, Horanyi J, Riesz P, Reismann P, Patocs A, Liko I, et al. Integrative molecular bioinformatics study of human adrenocortical tumors: microRNA tissue-specific target prediction, and pathway analysis. EndocrineRelated Cancer 200916 895-906. (https://doi.org/10.1677/ERC-09. 0096)

105 Szabo PM, Racz K \& Igaz P. Underexpression of C-myc in adrenocortical cancer: a major pathogenic event? Hormone and Metabolic Research 201143 297-299. (https://doi. org/10.1055/s-0031-1273762)

106 Liu J, Voutilainen R, Kahri AI \& Heikkila P. Expression patterns of the c-myc gene in adrenocortical tumors and pheochromocytomas. Journal of Endocrinology 1997152 175-181. (https://doi.org/10.1677/ joe.0.1520175)

107 Hickman ES, Moroni MC \& Helin K. The role of p53 and pRB in apoptosis and cancer. Current Opinion in Genetics and Development 200212 60-66. (https://doi.org/10.1016/S0959-437X(01)00265-9)

108 Luciakova K, Barath P, Li R, Zaid A \& Nelson BD. Activity of the human cytochrome $\mathrm{c} 1$ promoter is modulated by E2F. Biochemical Journal 2000351 251-256. (https://doi.org/10.1042/02646021:3510251)

109 Vorburger SA, Pataer A, Yoshida K, Liu Y, Lu X, Swisher SG \& Hunt KK. The mitochondrial apoptosis-inducing factor plays a role in E2F-1-induced apoptosis in human colon cancer cells. Annals of Surgical Oncology 200310 314-322. (https://doi.org/10.1245/ ASO.2003.05.021)

110 Xie W, Jiang P, Miao L, Zhao Y, Zhimin Z, Qing L, Zhu WG \& Wu M. Novel link between E2F1 and Smac/Diablo: proapoptotic Smac/ Diablo is transcriptionally upregulated by E2F1. Nucleic Acids Research 200634 2046-2055. (https://doi.org/10.1093/nar/gkl150)

111 Stanelle J \& Putzer BM. E2F1-induced apoptosis: turning killers into therapeutics. Trends in Molecular Medicine 200612 177-185. (https:// doi.org/10.1016/j.molmed.2006.02.002)

112 Stanelle J, Tu-Rapp H \& Putzer BM. A novel mitochondrial protein DIP mediates E2F1-induced apoptosis independently of p53. Cell Death and Differentiation 200512 347-357. (https://doi.org/10.1038/ sj.cdd.4401532)

113 Ragazzon B, Libe R, Assie G, Tissier F, Barreau O, Houdayer C, Perlemoine K, Audebourg A, Clauser E, Rene-Corail F, et al. Mass-array screening of frequent mutations in cancers reveals RB1 alterations in aggressive adrenocortical carcinomas. European Journal of Endocrinology 2014170 385-391. (https://doi.org/10.1530/EJE-13-0778) https://ec.bioscientifica.com https://doi.org/10.1530/EC-19-0114 (c) 2019 The authors Published by Bioscientifica Ltd

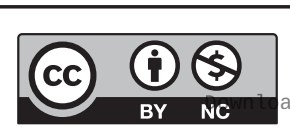

This work is licensed under a Creative Commons Attribution-NonCommercial 4.0 International License. ded from Bioscientifica.com at 04/26/2023 07:52:02AM 
114 Szabo PM, Tamasi V, Molnar V, Andrasfalvy M, Tombol Z, Farkas R, Kovesdi K, Patocs A, Toth M, Szalai C, et al. Meta-analysis of adrenocortical tumour genomics data: novel pathogenic pathways revealed. Oncogene 201029 3163-3172. (https://doi.org/10.1038/ onc.2010.80)

115 Cherradi N. MicroRNAs as potential biomarkers in adrenocortical cancer: progress and challenges. Frontiers in Endocrinology 20156195. (https://doi.org/10.3389/fendo.2015.00195)

116 Ozata DM, Caramuta S, Velazquez-Fernandez D, Akcakaya P, Xie H, Hoog A, Zedenius J, Backdahl M, Larsson C \& Lui WO. The role of microRNA deregulation in the pathogenesis of adrenocortical carcinoma. Endocrine-Related Cancer 201118 643-655. (https://doi. org/10.1530/ERC-11-0082)

117 Wang C, Sun Y, Wu H, Zhao D \& Chen J. Distinguishing adrenal cortical carcinomas and adenomas: a study of clinicopathological features and biomarkers. Histopathology 201464 567-576. (https:// doi.org/10.1111/his.12283)

118 Koperski Ł, Kotlarek M, Swierniak M, Kolanowska M, Kubiak A, Gornicka B, Jazdzewski K \& Wojcicka A. Next-generation sequencing reveals microRNA markers of adrenocortical tumors malignancy. Oncotarget 20178 49191-49200. (https://doi.org/10.18632/ oncotarget.16788)

119 Wu Y, Wang W, Hu W, Xu W, Xiao G, Nie Q, Ouyang K \& Chen S. MicroRNA-205 suppresses the growth of adrenocortical carcinoma SW-13 cells via targeting Bcl-2. Oncology Reports 201534 3104-3110. (https://doi.org/10.3892/or.2015.4295)

120 Soon PS, Tacon LJ, Gill AJ, Bambach CP, Sywak MS, Campbell PR, Yeh MW, Wong SG, Clifton-Bligh RJ, Robinson BG, et al. miR195 and miR-483-5p identified as predictors of poor prognosis in adrenocortical cancer. Clinical Cancer Research 200915 7684-7692. (https://doi.org/10.1158/1078-0432.CCR-09-1587)

121 Liu L, Chen L, Xu Y, Li R \& Du X. microRNA-195 promotes apoptosis and suppresses tumorigenicity of human colorectal cancer cells. Biochemical and Biophysical Research Communications 2010400 236-240. (https://doi.org/10.1016/j.bbrc.2010.08.046)

122 Patel MP, Masood A, Patel PS \& Chanan-Khan AA. Targeting the Bcl-2. Current Opinion in Oncology 200921 516-523. (https://doi. org/10.1097/CCO.0b013e328331a7a4)

123 Day TW \& Safa AR. RNA interference in cancer: targeting the anti-apoptotic protein C-FLIP for drug discovery. Mini Reviews in Medicinal Chemistry 20099 741-748. (https://doi. org/10.2174/138955709788452748)

124 Flack MR, Pyle RG, Mullen NM, Lorenzo B, Wu YW, Knazek RA, Nisula BC \& Reidenberg MM. Oral gossypol in the treatment of metastatic adrenal cancer. Journal of Clinical Endocrinology and Metabolism 199376 1019-1024. (https://doi.org/10.1210/ jc.76.4.1019)

125 Schteingart DE, Benitez R, Bradford C, Narayan A \& Wang S. Expression of anti-apoptosis genes determines the response of adrenal cancer to apoptosis-inducing chemotherapy. Anticancer Research 201030 4805-4809.

126 Oliver CL, Miranda MB, Shangary S, Land S, Wang S \& Johnson DE. (-)-Gossypol acts directly on the mitochondria to overcome Bcl2- and Bcl-X(L)-mediated apoptosis resistance. Molecular Cancer Therapeutics 20054 23-31.

127 Wu YW, Chik CL, Albertson BD, Linehan WM \& Knazek RA. Inhibitory effects of gossypol on adrenal function. Acta Endocrinologica $1991 \mathbf{1 2 4} 672-678$.

128 Liu S, Kulp SK, Sugimoto Y, Jiang J, Chang HL, Dowd MK, Wan P \& Lin YC. The (-)-enantiomer of gossypol possesses higher anticancer potency than racemic gossypol in human breast cancer. Anticancer Research 200222 33-38.

129 Huang YW, Wang LS, Chang HL, Ye W, Dowd MK, Wan PJ \& Lin YC. Molecular mechanisms of (-)-gossypol-induced apoptosis in human prostate cancer cells. Anticancer Research 200626 1925-1933.
130 Stein MN, Hussain M, Stadler WM, Liu G, Tereshchenko IV, Goodin S, Jeyamohan C, Kaufman HL, Mehnert J \& DiPaola RS. A Phase II study of AT-101 to overcome Bcl-2-mediated resistance to androgen deprivation therapy in patients With newly diagnosed castration-sensitive metastatic prostate cancer. Clinical Genitourinary Cancer 201614 22-27. (https://doi.org/10.1016/j.clgc.2015.09.010)

131 Anderson MA, Huang D \& Roberts A. Targeting BCL2 for the treatment of lymphoid malignancies. Seminars in Hematology 201451 219-227. (https://doi.org/10.1053/j.seminhematol.2014.05.008)

132 Baggstrom MQ, Qi Y, Koczywas M, Argiris A, Johnson EA, Millward MJ, Murphy SC, Erlichman C, Rudin CM, Govindan R, et al. A phase II study of AT-101 (Gossypol) in chemotherapysensitive recurrent extensive-stage small cell lung cancer. Journal of Thoracic Oncology 20116 1757-1760. (https://doi.org/10.1097/ JTO.0b013e31822e2941)

133 Zhu Y, Wang M, Zhao X, Zhang L, Wu Y, Wang B \& Hu W. Rottlerin as a novel chemotherapy agent for adrenocortical carcinoma. Oncotarget 20178 22825-22834. (https://doi.org/10.18632/ oncotarget.15221)

134 Xu L, Qi Y, Xu Y, Lian J, Wang X, Ning G, Wang W \& Zhu Y. Co-inhibition of EGFR and IGF1R synergistically impacts therapeutically on adrenocortical carcinoma. Oncotarget 20167 36235-36246. (https://doi.org/10.18632/oncotarget.8827)

135 Assie G, Letouze E, Fassnacht M, Jouinot A, Luscap W, Barreau O, Omeiri H, Rodriguez S, Perlemoine K, Rene-Corail F, et al. Integrated genomic characterization of adrenocortical carcinoma. Nature Genetics 201446 607-612. (https://doi.org/10.1038/ng.2953)

136 Khoo KH, Verma CS \& Lane DP. Drugging the p53 pathway: understanding the route to clinical efficacy. Nature Reviews: Drug Discovery 201413 217-236. (https://doi.org/10.1038/nrd4236)

137 Xiao M \& Li W. Recent advances on small-molecule survivin inhibitors. Current Medicinal Chemistry 2015221136 - 1146. (https:// doi.org/10.2174/0929867322666150114102146)

138 Garg H, Suri P, Gupta JC, Talwar GP \& Dubey S. Survivin: a unique target for tumor therapy. Cancer Cell International 201616 49-49. (https://doi.org/10.1186/s12935-016-0326-1)

139 Hassan M, Watari H, AbuAlmaaty A, Ohba Y \& Sakuragi N. Apoptosis and molecular targeting therapy in cancer. BioMed Research International 20142014 1-23. (https://doi.org/10.1155/2014/150845)

140 Hanahan D \& Weinberg RA. The hallmarks of cancer. Cell 2000100 57-70. (https://doi.org/10.1016/S0092-8674(00)81683-9)

141 Borges KS, Andrade AF, Silveira VS, Marco Antonio DS, Vasconcelos EJR, Antonini SRR, Tone LG \& Scrideli CA. The aurora kinase inhibitor AMG 900 increases apoptosis and induces chemosensitivity to anticancer drugs in the NCI-H295 adrenocortical carcinoma cell line. Anti-Cancer Drugs 201728 634-644. (https://doi. org/10.1097/CAD.0000000000000504)

142 Cheng Y, Kerppola RE \& Kerppola TK. ATR-101 disrupts mitochondrial functions in adrenocortical carcinoma cells and in vivo. Endocrine-Related Cancer 201623 1-19. (https://doi. org/10.1530/ERC-15-0527)

143 Subramanian C, Kuai R, Zhu Q, White P, Moon JJ, Schwendeman A \& Cohen MS. Synthetic high-density lipoprotein nanoparticles: a novel therapeutic strategy for adrenocortical carcinomas. Surgery 2016159 284-294. (https://doi.org/10.1016/j.surg.2015.08.023)

144 Liu J, Xu M, Zhao Y, Ao C, Wu Y, Chen Z, Wang B, Bai X, Li M \& $\mathrm{Hu} \mathrm{W}$. n-3 polyunsaturated fatty acids abrogate mTORC1/2 signaling and inhibit adrenocortical carcinoma growth in vitro and in vivo. Oncology Reports 201635 3514-3522. (https://doi.org/10.3892/ or.2016.4720)

145 Drelon C, Berthon A, Mathieu M, Ragazzon B, Kuick R, Tabbal H, Septier A, Rodriguez S, Batisse-Lignier M, Sahut-Barnola I, et al. EZH2 is overexpressed in adrenocortical carcinoma and is associated with disease progression. Human Molecular Genetics 201625 2789-2800. (https://doi.org/10.1093/hmg/ddw136) https://ec.bioscientifica.com https://doi.org/10.1530/EC-19-0114
(C) 2019 The authors Published by Bioscientifica Ltc

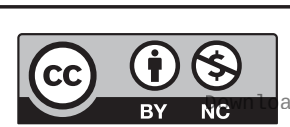

This work is licensed under a Creative Commons Attribution-NonCommercial 4.0 International License. ded from Bioscientifica.com at 04/26/2023 07:52:02AM 
146 Xu Y, Dong B, Huang J, Kong W, Xue W, Zhu Y, Zhang J \& Huang Y. Sphingosine kinase 1 is overexpressed and promotes adrenocortical carcinoma progression. Oncotarget 20167 3233-3244. (https://doi. org/10.18632/oncotarget.6564)

147 Chimento A, Sirianni R, Casaburi I, Zolea F, Rizza P, Avena P, Malivindi R, De Luca A, Campana C, Martire E, et al. GPER agonist G-1 decreases adrenocortical carcinoma (ACC) cell growth in vitro and in vivo. Oncotarget 20156 19190-19203. (https://doi org/10.18632/oncotarget.4241)

148 Poli G, Cantini G, Armignacco R, Fucci R, Santi R, Canu L, Nesi G, Mannelli $\mathrm{M} \&$ L Luconi M. Metformin as a new anti-cancer drug in adrenocortical carcinoma. Oncotarget 20167 49636-49648. (https:// doi.org/10.18632/oncotarget.10421)

149 Sbiera S, Leich E, Liebisch G, Sbiera I, Schirbel A, Wiemer L, Matysik S, Eckhardt C, Gardill F, Gehl A, et al. Mitotane inhibits sterol-O-acyl transferase 1 triggering lipid-mediated endoplasmic reticulum stress and apoptosis in adrenocortical carcinoma cells. Endocrinology 2015156 3895-3908. (https://doi.org/10.1210/ en.2015-1367)
150 Waszut U, Szyszka P \& Dworakowska D. Understanding mitotane mode of action. Journal of Physiology and Pharmacology 201768 $13-26$

151 Hescot S, Amazit L, Lhomme M, Travers S, DuBow A, Battini S, Boulate G, Namer IJ, Lombes A, Kontush A, et al. Identifying mitotane-induced mitochondria-associated membranes dysfunctions: metabolomic and lipidomic approaches. Oncotarget 20178 109924-109940. (https://doi.org/10.18632/ oncotarget.18968)

152 Satoh K, Zhang L, Zhang Y, Chelluri R, Boufraqech M, Nilubol N, Patel D, Shen M \& Kebebew E. Identification of niclosamide as a novel anticancer agent for adrenocortical carcinoma. Clinical Cancer Research 201622 3458-3466. (https://doi.org/10.1158/1078-0432. CCR-15-2256)

153 Batisse-Lignier M, Sahut-Barnola I, Tissier F, Dumontet T, Mathieu M, Drelon C, Pointud JC, Damon-Soubeyrand C, Marceau G, Kemeny JL, et al. $\mathrm{P} 53 / \mathrm{Rb}$ inhibition induces metastatic adrenocortical carcinomas in a preclinical transgenic model. Oncogene 201736 4445-4456. (https://doi.org/10.1038/onc.2017.54)

Received in final form 3 April 2019

Accepted 11 April 2019

Accepted Preprint published online 11 April 2019 https://ec.bioscientifica.com

https://doi.org/10.1530/EC-19-0114 (c) 2019 The authors Published by Bioscientifica Ltd

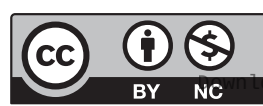

This work is licensed under a Creative Commons Attribution-NonCommercial 4.0 International License. ded from Bioscientifica.com at 04/26/2023 07:52:02AM via free access 